\section{MODIFICATION EQUATIONS OF AIR BUBBLES DISTRIBUTIONS AT SELF-AIR ENTRAINMENT CONDITION}

Yeri Sutopoa, Budi S. Wignyosukartob, Bambang Yulistyantob, Istiartob, Nor Hayati Abdul Hamidc

aDepartment of Civil Engineering, Faculty of Engineering, Universitas Negeri Semarang, Jawa Tengah, Semarang, Indonesia 50221

bCivil Engineering and Environment Department, Faculty of Engineering, Universitas Gadjah Mada, Jalan Grafika No. 2, Yogyakarta, Indonesia 55281

clnstitute for Infrastructure Engineering Sustainable and Management, Universiti Teknologi MARA, 40450 Shah Alam, Selangor, Malaysia
Article history

Received

1 April 2018

Received in revised form

20 November 2019

Accepted

16 January 2020

Published online

27 February 2020

*Corresponding author yerisutopo@mail.unnes.ac.id

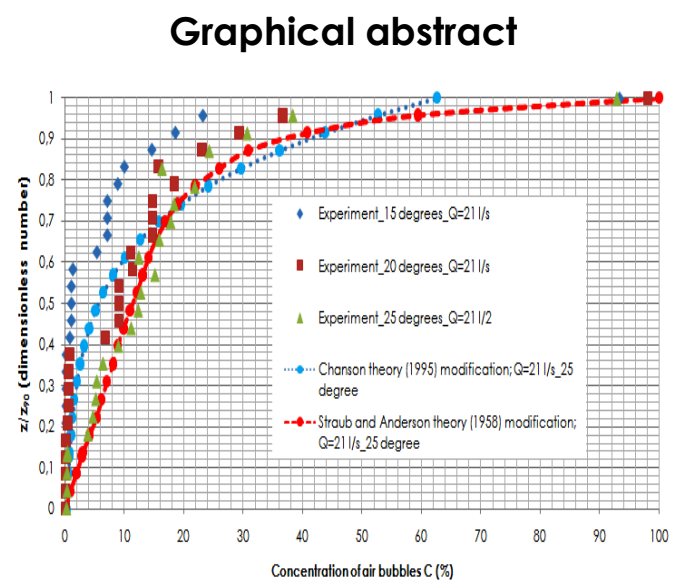

Concentration ofair bubbles $\mathrm{C}$ (\%)

\begin{abstract}
The Chanson's equation for distribution of air bubbles in vertical direction in the developing zone at self-air entrainment condition is used when the air bubbles concentration at the flow surface is $90 \%$. Otherwise, if this condition is not satisfying, then the equations of Straub and Anderson can be used. The results of these two equations are not similar with experimental results. Therefore, these two equations need to be modified accordingly. These modification equations can also be used to predict the air bubbles distributions in vertical direction. Hence, the main objective of this study is to modify these equations for vertical air concentration distribution in the developing zone and validate them with experimental results. The steep channel in the form of flume with $10 \mathrm{~m}$ long, $0.2 \mathrm{~m}$ wide and $0.4 \mathrm{~m}$ high with slopes varies between $20^{\circ}$ and $25^{\circ}$ were used in this experimental work. The discharge water was $9 \mathrm{l} / \mathrm{s}, 12 \mathrm{l} / \mathrm{s}$ and $21 \mathrm{l} / \mathrm{s}$ with Froude numbers between 6.9 to 8.0. The Thomson weir (V Notch) was used to calibrate the discharge flow of water. A set of video cameras was used to record the motion pictures of the air bubbles. The air bubble was analyzed using Ulead Video Studio 11 software program equipped with Imagej software. The results of this study indicates that the modifications of equations of Straub and Anderson were the equation air concentration distribution $(C)$ in the underlying zone value was $0.647 \mathrm{~m}$ at $20^{\circ}$ slope of channel bed, the equation air concentration distribution (C) in the underlying zone the value was $0.542 \mathrm{~m}$ at $25^{\circ}$ slope and the equation in the mixing zone remained the same. The original Chanson equation was modified mainly in terms of the hyperbolic tangent (tanh) equation which originally had a power of 2 while the modification was 0.8 ; and the $C_{e}$ was $0.9 \sin$ a. whereas at the modified Chanson's equation, $C_{e}$ was converted into $C_{e}=0.6$ $\sin a$.
\end{abstract}

Keywords: Air bubble distribution equation, developing zone, self-air entrainment (c) 2020 Penerbit UTM Press. All rights reserved

\subsection{INTRODUCTION}

The hydraulic conditions in the spillway involve four main part consisting of the upstream crest profile, downstream crest profile, the sloping face, and the energy dissipator at the toe. Upstream of the crest, the flow is subcritical; the flow changes its state from subcritical to supercritical after the crest because the 
crest is followed by a steep sloping face [1]. The supercritical flow occurs in the chute spillway. According to past researchers, the self-air entrainment regime in the spillway involved three regions which are no air entrainment, developing and fully developed regions [2-3]. The air entrainment area in no air entrainment and developing regions can cause erosion and cavitation. This conjecture is supported that erosion can occur in areas where pressure is low and in areas where air bubbles have not touch the channel bed or in developing areas [4].

From previous studies on air entrainment in steep open channels which had been conducted by two researchers [5-6] did not include the modification equations by Straub and Anderson. Therefore, the aim of this present study is to determine the distribution of air bubbles concentrations under conditions of self-air entrainment by modifying the Straub and Anderson equations. The distribution of air bubbles is considered in mixing and underlying zones of the developing area. The values of bed slopes of the channels used are $18^{\circ}$ and $24^{\circ}$. In addition, the flow discharges used are $1.2 \mathrm{ft} / \mathrm{s}, 1.7 \mathrm{ft} / \mathrm{s}$, and $2.2 \mathrm{ft} / \mathrm{s}$. Subsequently, the air bubble concentration data which were obtained from experimental work are compared with the air bubble distribution curve proposed by previous researchers [7].

Up to date, most of the equation which is normally used to predict the distribution of air bubbles in the no air entrainment and developing zones were developed by Chanson [8] and Straub [7]. The Straub equation can be used if the assumed concentration of air bubbles on the surface of the flow reached $90 \%$ or more. Furthermore, the Straub equation also can be used to predict the distribution of air bubbles even though the assumed concentration of air bubbles on the surface of the water flow did not reach $90 \%$. If the surface conditions of the flow had reached $90 \%$, then both equations of Chanson and Straub can be used together.

These two equations were developed actually cannot be applied under developing areas especially in the underlying zone [7-8]. The main reason is that the area of developing air bubbles did not reach the bottom part of the water flow. On the other hand, Falvey [2] stated that until now no one had developed equality equation in this area based on visual observations during experimental work. Lay [5] had used the equation of air bubbles distribution which had been proposed by Straub [7] to predict the distribution of air bubbles concentrations in the developing regions. Lay [5] found that in developing regions, the distribution of air bubbles cannot be explained by Straub [7] because the concentration of air bubbles near the bed is very small. It is because the area of developing air bubbles had not yet reached the bed of the water flow.

The equation of the distribution of air bubbles concentrations proposed by Straub [7] is also shown in the monograph [2]. According to Straub [7], the distribution of air bubbles can be divided into the underlying and the mixing zones. Equations in the underlying zone involve parameters of normal depth, concentration of air bubbles at the depth of the transition, and depth of the transition. The equations in the mixing zone involve the normal distribution function.

The experimental work which had been conducted by Sutopo [10] found that the two equations developed by Straub [7] and Chanson [8] were not suitable when compared with the experimental results. Therefore, the two equations must be modified accordingly based on their conditions. The result of this study is the modification of the equations developed by Straub [7] and Chanson [8]. These modifications equations can be used precisely and accurately to predict the distribution of air bubbles in vertical direction. This modification on the equation can be referred by other researchers to test its precision and accuracy of the experimental results.

The equation developed by Chanson can be used to predict the distribution of air bubbles in the body of water on the chute spillway if the assumed concentration of air bubbles on the flow surface has reached $90 \%$ or more. Whereby, the equation developed by Straub can be used to predict the distribution of air bubbles even though the assumed concentration of air bubbles on the surface of the flow has not reached $90 \%$. Equation by Straub actually cannot be applied in the developing region, especially in the equation in the underlying zone. It is because the developing air bubbles have not yet reached the bottom of the flow. Therefore, a modified equation about the distribution of air bubbles in the body of water in the chute spillway is required which has high accuracy if used to predict it.

Based on the description of the background and problem as mentioned above, the objectives of this study are to find of the equation for the distribution of modified air bubbles from equation Chanson on the condition that the percentage of air bubbles on the surface of the flow has reached $90 \%$; and to find of the modified air bubble distribution equation Straub on the condition that the percentage of air bubbles on the surface flow has not reached $90 \%$.

\subsection{RESEARCH METHODOLOGY}

This research work was conducted at the Hydraulic Laboratory, Department of Civil and Environmental Engineering (JTSL), Faculty of Engineering, Universitas Gadjah Mada, Yogyakarta, Indonesia. The study was conducted on July 1, 2014 until August 15, 2014 [10]. In this study, a steep flume with length of $10 \mathrm{~m}$, width of $0.2 \mathrm{~m}$, height of $0.4 \mathrm{~m}$ and slopes vary between $20^{\circ}$ and $25^{\circ}$ was constructed in one of the walls of a reservoir. The slope of bed flow of the flume which was $a=20^{\circ}$, and $a=25^{\circ}$ was based on Chanson [8]. It is also considers that the flume steep slope was $a \geq 20^{\circ}$. In this research work, flume steep slope at $a=20^{\circ}$ and $25^{\circ}$ were chosen. The flow of water into the flume which was carried out from the upper reservoir was 
controlled by the valve. The discharge water was varied from $9 \mathrm{l} / \mathrm{s}, 12 \mathrm{l} / \mathrm{s}$ and $21 \mathrm{l} / \mathrm{s}$ with Froude number between 6.9 to 8.0. The Thomson weir ( $V$ Notch) was used to calibrate discharge water flow. A set of video cameras was used to record the motion pictures of air bubbles. Air bubble analysis was conducted using Ulead Video Studio 11 software program equipped with Imagej software [10].

The air concentration was measured at $3 \mathrm{~cm}$ from the side walls of the flume to the axis of the flume (cross-sectional). In the longitudinal direction, the air concentration was measured at $X=650 \mathrm{~cm}$ and $X=750$ $\mathrm{cm}$ from the inlet flume. The location of measurement was along the "developing zone". In the vertical direction or perpendicular to the flow (normal depth), the air concentration was measured using 25 categories of depth class, depending on the normal depth of the flow [10]. Table 1 tabulates the tools and instruments used in this study.

Table 1 Tools and instruments used in research [10]

\begin{tabular}{|c|c|}
\hline $\begin{array}{l}\text { Types of Tools } \\
\text { and Instruments }\end{array}$ & Specification \\
\hline Flume & $\begin{array}{l}\text { This flume is the main equipment in } \\
\text { conducting experiments that is equipped } \\
\text { with volumetric tanks. This flume is } 10 \mathrm{~m} \text { long, } \\
0.4 \mathrm{~m} \text { high and } 0.2 \mathrm{~m} \text { wide. }\end{array}$ \\
\hline Water pump & $\begin{array}{l}\text { Water pumps that have a discharge water of } \\
9 \mathrm{l} / \mathrm{s} ; 12 \mathrm{l} / \mathrm{s} \text { and } 21 \mathrm{l} / \mathrm{s}\end{array}$ \\
\hline Water tower & $\begin{array}{l}\text { The height of the water tower is } 4 \mathrm{~m} \text { that is } \\
\text { built on the laboratory floor. This water tower } \\
\text { is used to support the water tank located } \\
\text { above it }\end{array}$ \\
\hline Water tank & $\begin{array}{l}\text { The water tank in the downstream flume } \\
\text { which has a length of } 4 \mathrm{~m} \text { and a width of } 2 \mathrm{~m} \text {. } \\
\text { This water tank is located at the bottom or } \\
\text { bottom of the laboratory floor }\end{array}$ \\
\hline $\begin{array}{l}\text { Instrument for } \\
\text { measuring the } \\
\text { diameter of air } \\
\text { bubbles }\end{array}$ & $\begin{array}{l}\text { CCTV cameras, Ulead Video Studio } 11 \\
\text { software, Imagej software, a program used } \\
\text { for data analysis about air bubble distribution, } \\
\text { and Trace program are software for } \\
\text { determining the position of air bubbles. }\end{array}$ \\
\hline $\begin{array}{l}\text { Multimedia } \\
\text { computer }\end{array}$ & $\begin{array}{l}\text { This computer is used to analyze image } \\
\text { capture data by video cameras and } \\
\text { cameras equipped with Ulead Video Studio } \\
11 \text {, Imagej, and Trace programs }\end{array}$ \\
\hline Data logger & $\begin{array}{l}\text { Data loggers are used to store, analyze, and } \\
\text { change the mechanical and electrical } \\
\text { phenomenon of the sensor into the ADC } \\
\text { scale }\end{array}$ \\
\hline Imagej & $\begin{array}{l}\text { Software used to measure air bubble } \\
\text { dimensions on a real scale ( } \mathrm{mm}) \text {, compiled in } \\
\text { Delphi }\end{array}$ \\
\hline Tripod & $\begin{array}{l}\text { A tripod is used to place the video camera at } \\
\text { a specified height so it does not move. Tripot } \\
\text { used is the brand Vanguard type CT-248-6 }\end{array}$ \\
\hline Lights & $\begin{array}{l}\text { The lamp used is a } 500 \text { watt capacity } 4 \\
\text { halogen lamp }\end{array}$ \\
\hline Tracing paper & $\begin{array}{l}\text { In this research tracing paper is used as a } \\
\text { screen so that the light spreads evenly in the } \\
\text { flume. In addition, combined with thin blue } \\
\text { paper so that the light becomes softer }\end{array}$ \\
\hline
\end{tabular}
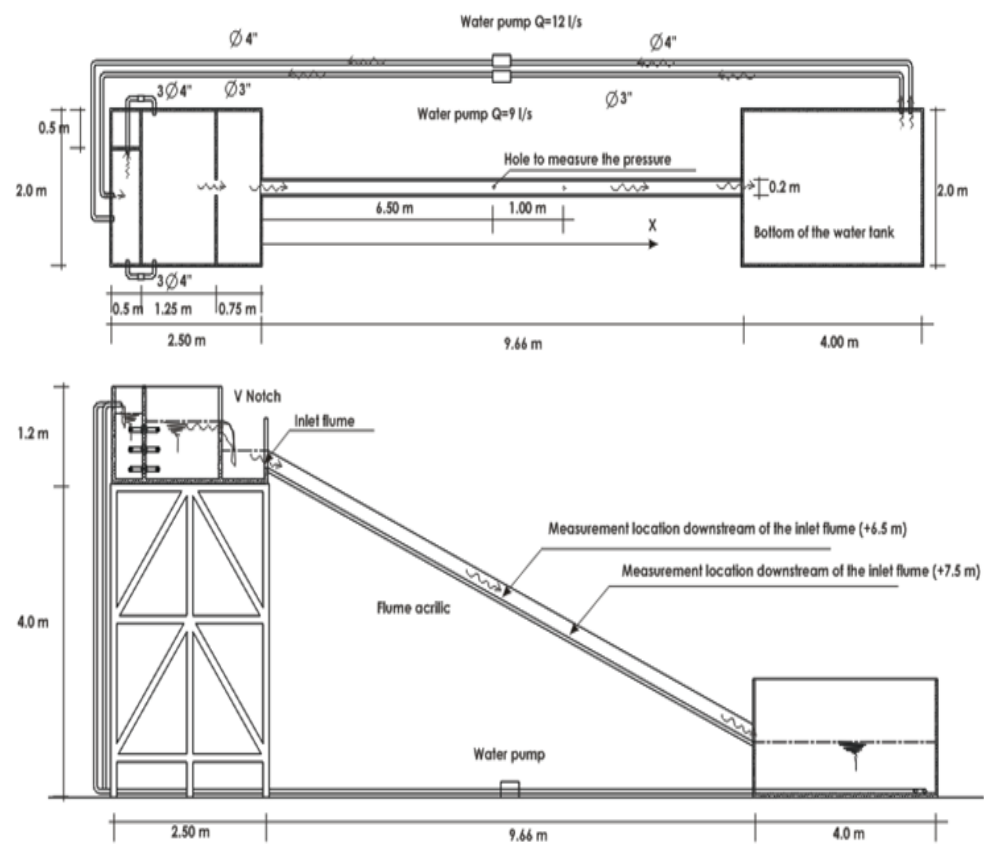

Figure 2 The layout of device and instruments of the study

The layout of the lower part of the water tank, the upper part of the water tank, the pump, the spout, and the hole to measure the pressure at the bed of the flow are presented in Figure 2.
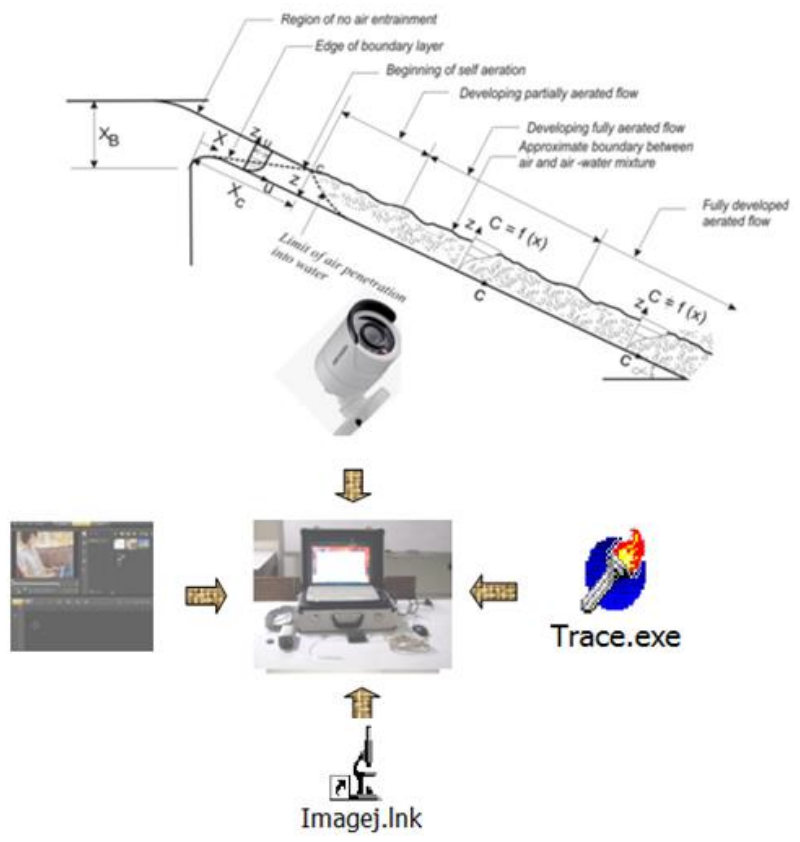

Figure 3 The steps of determining the distribution of air bubble concentrations 
The steps to determine the distribution of air bubble concentration $\mathrm{C}$ are shown in Figure 3. There are six steps involve in this procedure as listed below:

(1) Capture the air bubble images using a Closed Circuit Television (CCTV) camera equipped with a Charge-Coupled Device (CCD) sensor. Air bubbles are measured at $3 \mathrm{~cm}$ from the flume sidewall in the direction of the axles of the flume. In the longitudinal direction, air bubbles are measured at $X=650 \mathrm{~cm}$ and $X=750 \mathrm{~cm}$.

(2) Read the air bubble images using video capture software.

(3) Store the video images in the video capture software files.

(4) Convert the video images into still images using the Batch Convert menu.

(5) Measure the dimensions of the air bubbles with Image software.

(6) Imagej is used to process images of air bubbles that were originally in units of pixels into units of length and area of air bubbles.

(7) Calculate the distribution of concentrations of air bubbles using Excel software.

The distribution of air bubbles is measured in the vertical or perpendicular flow (normal depth) in which the number of depth classes is divided into 15 to 25 categories. The depth range in each class is similar, that is $1.2 \mathrm{~mm}$. Therefore, based on the number of classes and concentrations of air bubbles in each class, it can be arranged the distribution of air bubbles.

The error analysis was conducted using Equation 1 [11-13]:

$$
\text { error }=\left|\frac{C_{t}-C_{\exp }}{C_{\exp }}\right| x 100 \% .
$$

Where $\mathrm{C}_{+}$is theoretical concentration of air bubbles. Cexp is the concentration of air bubbles experimental results. The accuracy was calculated using Equation 2 as follows:

$$
A_{C}=100 \%-\text { error }
$$

\subsection{RESULTS AND DISCUSSION}

3.1 Air bubble Concentration Distribution Profile at The point of $6.5 \mathrm{~m}$ and $7.5 \mathrm{~m}$ from the Inlet Flume

Based on Figure 4 and Figure 5, the distribution of experimental air bubble concentration on the vertical direction at $6.5 \mathrm{~m}$ and $7.5 \mathrm{~m}$ on downstream of inlet flume with slope of $a=15^{\circ}, 20^{\circ}, 25^{\circ}$ and at $Q=21 \mathrm{l} / \mathrm{s}$ (underlying zone and mixing zone) follows the logarithm equation. At $7.5 \mathrm{~m}$ on the downstream of the inlet flume, the conditions of the air concentration follows as (1) at $a=20^{\circ}$ and $Q=9 \mathrm{l} / \mathrm{s}, 12 \mathrm{l} / \mathrm{s}$ and $21 \mathrm{l} / \mathrm{s}$, the air bubbles did not reach the channel bed; (2) at $\mathrm{a}=25^{\circ}$ and $\mathrm{Q}=9 \mathrm{l} / \mathrm{s}, 12 \mathrm{l} / \mathrm{s}$, the air bubbles did not reach the channel bed; and (c) at $a=25^{\circ}$ and $Q=21 \mathrm{l} / \mathrm{s}$, the air bubbles had reached the channel bed although its concentration was still $2.9 \%$. By referring to Bhajantri et al. [1], the air concentration distribution profile at the point of $7.5 \mathrm{~m}$ on the downstream of the inlet flume was categorized as fully aerated flow because the air concentration reached the bed of the channel, which amounted to $2.9 \%$. Therefore, the distribution profile of air bubbles at the point of $7.5 \mathrm{~m}$ on the downstream of the inlet flume was included to the fully aerated flow zone, and assumed in the initiation of a fully aerated flow. The area was also prone to phenomenon of cavitation [10].

3.2 The Comparison of Accuracy between [7] and [8] in Predicting Distribution of Air Concentration at Vertical Direction

Table 2 shows that at point of $6.5 \mathrm{~m}$ on the downstream of the outlet flume and the discharge flow was up to $12 \mathrm{l} / \mathrm{s}$, then Chanson [8] was not be used. It is because the concentration of air bubbles on the surface of the flow was less than $90 \%$. At point of $7.5 \mathrm{~m}$ on the downstream of the outlet flume and the discharge flow was up to $9 \mathrm{l} / \mathrm{s}$, then Chanson [8] was not used because the concentration of air bubbles on the surface of the flow was less than $90 \%$. The accuracy of Straub [7] was higher than that of Chanson [8]. However, these two equations should be modified to accurately predict the distribution of air concentration at vertical direction.

Table 2 Comparison of accuracy between Straub [7] and Chanson [8] in predicting the distribution of air concentration

\begin{tabular}{|c|c|c|c|c|}
\hline \multirow[t]{2}{*}{ Point } & \multirow[t]{2}{*}{$Q$ and $a$} & \multicolumn{2}{|c|}{$\begin{array}{l}\text { The accuracy of } \\
\text { empirical equation of } \\
\text { air concentration } \\
\text { distribution at vertical } \\
\text { direction }\end{array}$} & \multirow[t]{2}{*}{ Information } \\
\hline & & [7] in\% & [8]in\% & \\
\hline \multirow{6}{*}{ 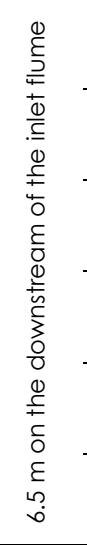 } & $\begin{array}{c}9 \mathrm{I} / \mathrm{s} \text { and } \\
20^{\circ} \\
(\mathrm{F}=6.9)\end{array}$ & 80.09 & - & \multirow{4}{*}{$\begin{array}{l}\text { The [8] was not } \\
\text { compared, } \\
\text { because the } \\
\text { concentration of } \\
\text { air bubble at the } \\
\text { flow surface } \\
\text { was<90\% }\end{array}$} \\
\hline & $\begin{array}{c}91 / \mathrm{s} \text { and } \\
25^{\circ} \\
(\mathrm{F}=7.1)\end{array}$ & 69.19 & - & \\
\hline & $\begin{array}{c}12 \mathrm{l} / \mathrm{s} \text { and } \\
20^{\circ} \\
(\mathrm{F}=7.4)\end{array}$ & 69.88 & - & \\
\hline & $\begin{array}{c}12 \mathrm{l} / \mathrm{s} \text { and } \\
25^{\circ} \\
(\mathrm{F}=7.5)\end{array}$ & 74.05 & - & \\
\hline & $\begin{array}{c}21 \mathrm{l} / \mathrm{s} \text { and } \\
20^{\circ} \\
(\mathrm{F}=7.8)\end{array}$ & 75.03 & 26.55 & $\begin{array}{l}\text { The [7] was more } \\
\text { accurate }\end{array}$ \\
\hline & $\begin{array}{c}21 \mathrm{l} / \mathrm{s} \text { and } \\
25^{\circ} \\
(\mathrm{F}=7.9)\end{array}$ & 74.52 & 28.53 & $\begin{array}{l}\text { The [7] was more } \\
\text { accurate }\end{array}$ \\
\hline \multirow{2}{*}{ 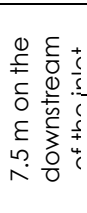 } & $\begin{array}{c}9 \mathrm{I} / \mathrm{s} \text { and } \\
20^{\circ} \\
(\mathrm{F}=7.2)\end{array}$ & 75.99 & - & \multirow{2}{*}{$\begin{array}{l}\text { The [8] was not } \\
\text { compared, } \\
\text { because the } \\
\text { concentration of } \\
\text { air bubble at the } \\
\text { flow surface } \\
\text { was<90\% }\end{array}$} \\
\hline & $\begin{array}{c}9 \mathrm{l} / \mathrm{s} \text { and } \\
25^{\circ} \\
(\mathrm{F}=7.3)\end{array}$ & 81,41 & - & \\
\hline
\end{tabular}
in vertical direction 


\begin{tabular}{|c|c|c|c|c|}
\hline \multirow[t]{6}{*}{ Point } & $Q$ and $a$ & \multicolumn{2}{|c|}{$\begin{array}{l}\text { The accuracy of } \\
\text { empirical equation of } \\
\text { air concentration } \\
\text { distribution at vertical } \\
\text { direction }\end{array}$} & \multirow[t]{2}{*}{ Information } \\
\hline & & [7] in\% & [8]in\% & \\
\hline & $\begin{array}{c}12 \mathrm{l} / \mathrm{s} \text { and } \\
20^{\circ} \\
(\mathrm{F}=7.6)\end{array}$ & 77.95 & 78.13 & $\begin{array}{l}\text { The accuracy of } \\
\text { both equations [7] } \\
\text { and [8] were } \\
\text { similar }\end{array}$ \\
\hline & $\begin{array}{c}12 \mathrm{l} / \mathrm{s} \text { and } \\
25^{\circ} \\
(\mathrm{F}=7.7)\end{array}$ & 75.58 & 87.08 & $\begin{array}{l}\text { The accuracy of } \\
\text { both equations [7] } \\
\text { and [8] were } \\
\text { similar }\end{array}$ \\
\hline & $\begin{array}{c}21 \mathrm{l} / \mathrm{s} \text { and } \\
20^{\circ} \\
(\mathrm{F}=7.9)\end{array}$ & 50.48 & 58.63 & $\begin{array}{l}\text { The accuracy of } \\
\text { both equations [7] } \\
\text { and [8] were } \\
\text { similar }\end{array}$ \\
\hline & $\begin{array}{c}21 \mathrm{l} / \mathrm{s} \text { and } \\
25^{\circ} \\
(\mathrm{F}=8.0)\end{array}$ & 70,31 & 25.62 & $\begin{array}{l}\text { The [7] was more } \\
\text { accurate }\end{array}$ \\
\hline
\end{tabular}

Source: The results of data analysis in 2017

where:

F : The Froude number

\subsection{The Modification of Equations as Recommended by Researchers}

The modification equations which recommended to the researchers based on the experimental work are as suggested herein.

1) For angle $\mathrm{a}=20^{\circ}$, the Equation 3 is recommended for value (C) as follows;

$$
C=C_{0}\left(\frac{z}{z_{t}-z}\right)^{0,647}
$$

where 0.647 in $\mathrm{m}$;

2) For slope $a=25^{\circ}$, the Equation 4 is recommended for value (C) as follow:

$$
C=C_{0}\left(\frac{z}{z_{t}-z}\right)^{0,542}
$$

where 0.542 was $\mathrm{m}$. The greater value of the slope angle in the channel bed leads to the smaller power value of $m$ in Equation (7) modification, especially in the underlying zone.

Meanwhile, the Equation 5 in the mixing zone remained the same as follows

$$
\frac{1-C_{m}}{1-C_{t}}=2\left(1-P_{g}\right)
$$

At this time, the air concentration was at $\mathrm{zt} / 2$ was equal to $0 \%$. Then, the parameter $\mathrm{C}_{0}$ (air concentration at the inner edge of the turbulent free zone) was used, but if $z_{t} / 2 \neq 0 \%$ (typically the air concentration reached the channel bed) then the parameter $C_{1}$ (the air concentration at $z_{t} / 2$ was used). At the channel bed slope of $20^{\circ}$, Equation 6 as stated below

$$
C=C_{1}\left(\frac{z}{z_{t}-z}\right)^{0,647}
$$

and at the channel bed slope of $25^{\circ}$, Equation 7 can be applied

$$
C=C_{1}\left(\frac{z}{z_{t}-z}\right)^{0,542}
$$

The original equation by Chanson [8] defined by Equation 8 as follows

$$
C=1-\tanh ^{2}\left(K^{\prime}-\frac{z / z 90}{2 D^{\prime}}\right)
$$

It was modified to Equation 9 as follows

$$
C=1-\tanh ^{0,8}\left(K^{\prime}-\frac{z / z_{90}}{2 D^{\prime}}\right)
$$

The $K^{\prime}$ and $D^{\prime}$ parameters were included $\mathrm{Ce}_{e}$ parameter. $\mathrm{C}_{e}$ is average air bubble concentration in vertical direction. At the original [8], the $\mathrm{C}_{e}=0.9 \sin \mathrm{a}$, whereas at the modified [8], Ce was converted into $\mathrm{C}_{\mathrm{e}}=0.6 \sin \mathrm{a}$.

\subsection{Accuracy of the Modified Equations of Straub [7] and Chanson [8]}

Table 3 shows the modified equation of Straub [7] in predicting the air concentration distribution at vertical direction was more accurate than the original. The increase in accuracy percentage was 3\%. Therefore, it can be synthesized that the modified of [7] was preferred in predicting the air concentration distribution at vertical direction in the developing zone at the self-air entrainment condition.

Figure 3 shows the modified Equation of [7] at the point of $6.5 \mathrm{~m}$ on the downstream from the inlet flume in predicting the concentration of air concentration distribution the vertical direction (C) was more accurate than the modified of [8]. The average accuracy of the modified of [7] equation was $78.68 \%$, while the modified of [8] is $49.34 \%$. Therefore, it can be synthesized that the modified equation of [7] was

\begin{tabular}{|c|c|c|c|c|}
\hline \multirow[t]{2}{*}{ Point } & \multirow[t]{2}{*}{$Q$ and $a$} & \multicolumn{2}{|c|}{$\begin{array}{c}\text { The accuracy of } \\
\text { empirical equation of air } \\
\text { concentration } \\
\text { distribution of vertical } \\
\text { direction }\end{array}$} & \multirow[t]{2}{*}{ Information } \\
\hline & & [7] in\% & $\begin{array}{c}\text { The } \\
\text { modified of } \\
\text { [7]in \% }\end{array}$ & \\
\hline \multirow{4}{*}{ 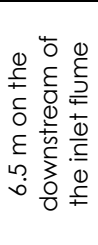 } & $\begin{array}{c}9 \mathrm{I} / \mathrm{s} \text { and } \\
20^{\circ}(\mathrm{F}=6.9)\end{array}$ & 80.09 & 82.77 & \multirow{4}{*}{ 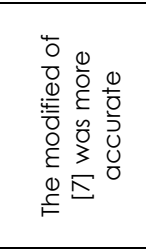 } \\
\hline & $\begin{array}{c}9 \mathrm{l} / \mathrm{s} \text { and } \\
25^{\circ}(\mathrm{F}=7.1)\end{array}$ & 69.19 & 79.98 & \\
\hline & $\begin{array}{l}12 \mathrm{I} / \mathrm{s} \text { and } \\
20^{\circ}(\mathrm{F}=7.4)\end{array}$ & 69.88 & 75.75 & \\
\hline & $\begin{array}{l}12 \mathrm{l} / \mathrm{s} \text { and } \\
25^{\circ}(\mathrm{F}=7.5)\end{array}$ & 74.05 & 79.91 & \\
\hline
\end{tabular}
preferred to predict the distribution air concentration (C) at the vertical direction at the point of $6.5 \mathrm{~m}$ of the downstream inlet flume.

Table 3 The comparison of accuracy between [7] with the [7] modified in predicting the distribution of vertical air bubbles concentration 


\begin{tabular}{|c|c|c|c|c|}
\hline \multirow[t]{4}{*}{ Point } & \multirow[t]{2}{*}{$Q$ and $a$} & \multicolumn{2}{|c|}{$\begin{array}{l}\text { The accuracy of } \\
\text { empirical equation of air } \\
\text { concentration } \\
\text { distribution of vertical } \\
\text { direction }\end{array}$} & \multirow[t]{4}{*}{ Information } \\
\hline & & [7] in\% & $\begin{array}{c}\text { The } \\
\text { modified of } \\
\text { [7]in \% }\end{array}$ & \\
\hline & $\begin{array}{l}21 \mathrm{l} / \mathrm{s} \text { and } \\
20^{\circ}(\mathrm{F}=7.8)\end{array}$ & 75.03 & 77.15 & \\
\hline & $\begin{array}{l}21 \mathrm{l} / \mathrm{s} \text { and } \\
25^{\circ}(\mathrm{F}=7.9)\end{array}$ & 74.52 & 76.54 & \\
\hline \multirow{6}{*}{ 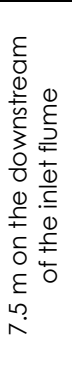 } & $\begin{array}{c}9 \mathrm{l} / \mathrm{s} \text { and } \\
20^{\circ}(\mathrm{F}=7.2)\end{array}$ & 75.99 & 76.49 & \multirow{6}{*}{ 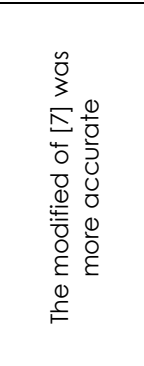 } \\
\hline & $\begin{array}{c}9 \mathrm{l} / \mathrm{s} \text { and } \\
25^{\circ}(\mathrm{F}=7.3)\end{array}$ & 81,41 & 82.23 & \\
\hline & $\begin{array}{l}12 \mathrm{l} / \mathrm{s} \text { and } \\
20^{\circ}(\mathrm{F}=7.6)\end{array}$ & 77.95 & 78.40 & \\
\hline & $\begin{array}{l}12 \mathrm{l} / \mathrm{s} \text { and } \\
25^{\circ}(\mathrm{F}=7.7)\end{array}$ & 75.58 & 76.42 & \\
\hline & $\begin{array}{l}21 \mathrm{l} / \mathrm{s} \text { and } \\
20^{\circ}(\mathrm{F}=7.9)\end{array}$ & 50.48 & 52.85 & \\
\hline & $\begin{array}{l}21 \mathrm{l} / \mathrm{s} \text { and } \\
25^{\circ}(\mathrm{F}=8.0)\end{array}$ & 70,31 & 72.08 & \\
\hline
\end{tabular}

Source: The results of data analysis in 2017

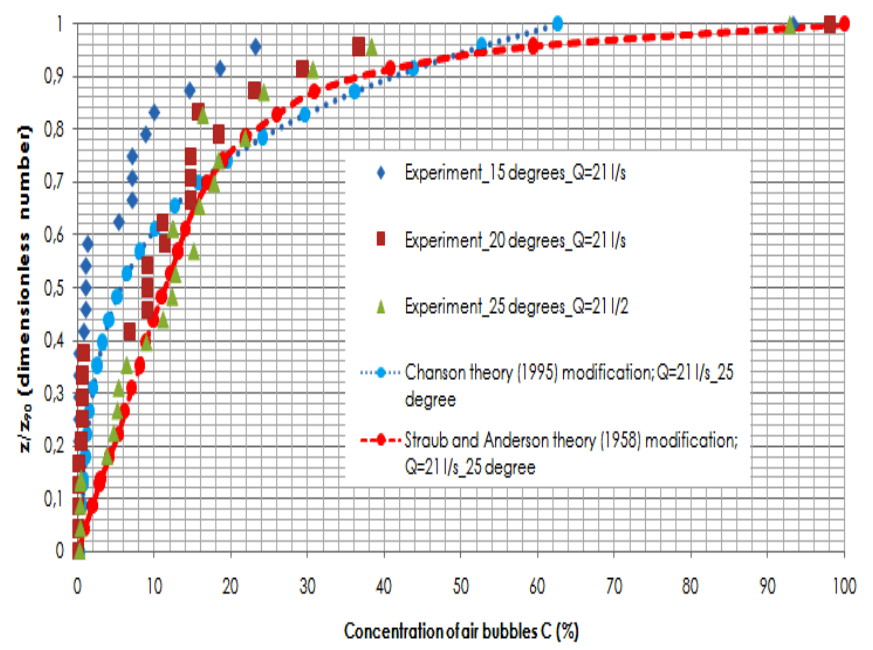

Figure 4 The accuracy of air concentration distribution of the modified equation of [7] and [8] at the point of $6.5 \mathrm{~m}$ from the inlet flume at $Q=21 \mathrm{l} / \mathrm{s}$, and $a=15^{\circ}, 20^{\circ}, 25^{\circ}$

The graph in Figure 4 was obtained from the results of experiments conducted in this study which used a flume with varying base slopes of $15^{\circ}, 20^{\circ}$, and $25^{\circ}$ at a discharge of $21 \mathrm{l} / \mathrm{s}$. The blue dashed line was the modified (8) equation where the parameters used were $21 \mathrm{l} / \mathrm{s}$ discharge and the bed slope of the flow was $25^{\circ}$. The red dashed line was the modified [7] equation where the parameters used were $21 \mathrm{l} / \mathrm{s}$ discharge and the bed slope of the flow was $25^{\circ}$ and at the point of $6.5 \mathrm{~m}$ from the inlet flume.

Based on Table 4, the modified of [8] in predicting the air concentration distribution at vertical direction was more accurate than that of [8]. The increase in percentage of average accuracy was $10.6 \%$. Therefore, it can be synthesized that the modified of [8] was preferred in predicting the air concentration distribution (C) in the vertical direction in the developing zone at the self-air entrainment condition.
From Figure 5, the modified equation of [7] at the point of $7.5 \mathrm{~m}$ on downstream from the inlet flume in predicting the distribution of air concentration of (C) at the vertical direction is more accurate than the modified equation of [8]. The average accuracy of the modified equation of [7] was $73.07 \%$. Meanwhile, the modified equation of [8] is $67.46 \%$. Therefore, it can be synthesized that the modified equation of [7] was preferred to predict the distribution air concentration (C) at the vertical direction at the point of $7.5 \mathrm{~m}$ of the inlet flume downstream.

The graph in Figure 5 was obtained from the experimental results in this study which used a flume with a basic slope of varying 15,20 , and 25 degrees at a discharge of $21 \mathrm{l} / \mathrm{s}$. The blue dashed line was the modified equation of [8] where the parameters used are $21 \mathrm{l} / \mathrm{s}$ discharge and the bed slope of the flow was 25 degrees. The red dashed line was the modified equation of [7] where the parameters used were $21 \mathrm{l} / \mathrm{s}$ discharge and the bed slope of the flow was 25 degrees and at the point of $7.5 \mathrm{~m}$ from the inlet flume.

Table 4 Comparison of accuracy between of [8] with the modified of [8] in predicting the distribution of air bubbles concentration at the vertical direction

\begin{tabular}{|c|c|c|c|c|}
\hline \multirow[t]{2}{*}{ Point } & \multirow[t]{2}{*}{$Q$ and $a$} & \multicolumn{2}{|c|}{$\begin{array}{c}\text { Accuracy of empirical } \\
\text { equation of air bubbles } \\
\text { concentration distribution at } \\
\text { vertical direction }\end{array}$} & \multirow[t]{2}{*}{ Information } \\
\hline & & [8] in\% & $\begin{array}{l}\text { The modified } \\
\text { of }[8] \text { in } \%\end{array}$ & \\
\hline \multirow{2}{*}{ 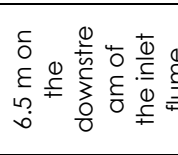 } & $\begin{array}{l}21 \mathrm{l} / \mathrm{s} \text { and } \\
20^{\circ}(\mathrm{F}=7.8)\end{array}$ & 26.55 & 43.98 & \multirow{2}{*}{$\begin{array}{l}\text { The Modified } \\
\text {-of [8] } \\
\text { equation } \\
\text { was more } \\
\text { accurate }\end{array}$} \\
\hline & $\begin{array}{l}21 \mathrm{l} / \mathrm{s} \text { and } \\
25^{\circ}(\mathrm{F}=7.9)\end{array}$ & 28.53 & 54.71 & \\
\hline \multirow{4}{*}{ 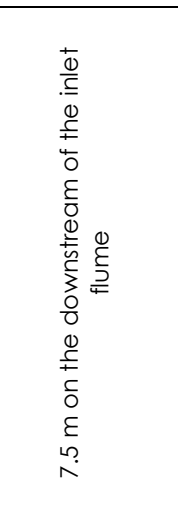 } & $\begin{array}{l}12 \mathrm{l} / \mathrm{s} \text { and } \\
20^{\circ}(\mathrm{F}=7.6)\end{array}$ & 78.13 & 93.59 & $\begin{array}{l}\text { The Modified } \\
\text { of [8] } \\
\text { equation } \\
\text { was more } \\
\text { accurate } \\
\end{array}$ \\
\hline & $\begin{array}{l}12 \mathrm{l} / \mathrm{s} \text { and } \\
25^{\circ}(\mathrm{F}=7.7)\end{array}$ & 87.08 & 87.82 & $\begin{array}{l}\text { The } \\
\text { accuracy of } \\
\text { both } \\
\text { equations } \\
\text { [8] and [8] } \\
\text { modification } \\
\text { were similar }\end{array}$ \\
\hline & $\begin{array}{l}21 \mathrm{l} / \mathrm{s} \text { and } \\
20^{\circ}(\mathrm{F}=7.9)\end{array}$ & 58.63 & 61.09 & \multirow{2}{*}{$\begin{array}{l}\text { The Modified } \\
\text {-of [8] } \\
\text { equation } \\
\text { was more } \\
\text { accurate }\end{array}$} \\
\hline & $\begin{array}{l}21 \mathrm{l} / \mathrm{s} \text { and } \\
25^{\circ}(\mathrm{F}=8.0)\end{array}$ & 25.62 & 27.37 & \\
\hline
\end{tabular}

Source: The results of data analysis in 2017

Therefore, it can be synthesized that the modified equation of [7] was preferred to predict the distribution of air concentration in the vertical direction in the developing zone at the selfairentrainment condition than the modified equation of [8]. 


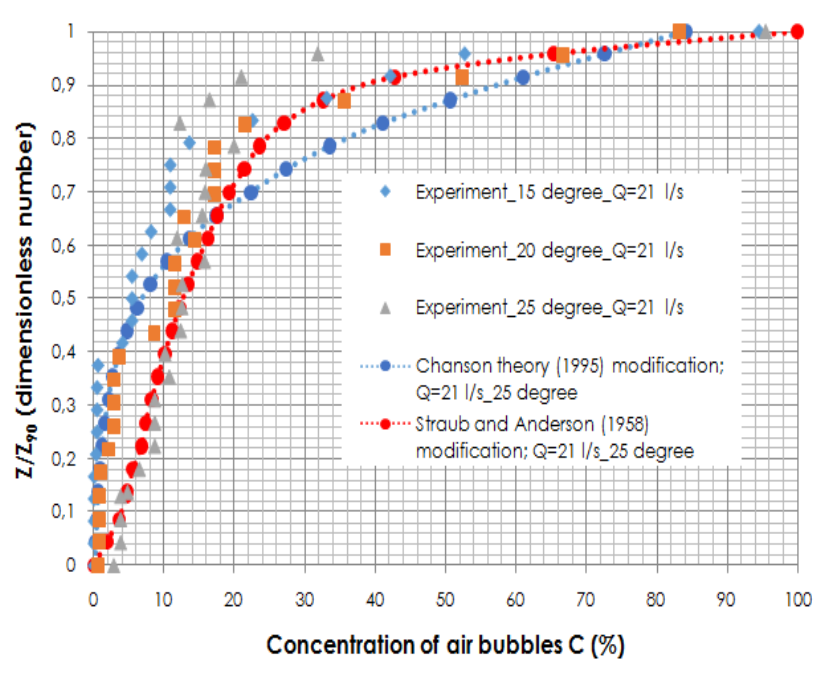

Figure 5 The accuracy of air concentration distribution of the modified equation of [7] and [8] at the point of $7.5 \mathrm{~m}$ from the inlet flume at $Q=21 \mathrm{l} / \mathrm{s}$, and $a=15^{\circ}, 20^{\circ}, 25^{\circ}$

\subsection{CONCLUSION AND RECOMMENDATIONS}

It can be concluded that the modified Straub and Anderson equations have the value of air concentration distribution $\mathrm{C}$ is $0.647 \mathrm{~m}$ at $20^{\circ}$ slope of channel bed and $\mathrm{C}$ is $0.542 \mathrm{~m}$ at $25^{\circ}$ slope in the underlying zone. The original Chanson (1995) equation was modified mainly in terms of the hyperbolic tangent (tanh) equation which originally had a power of 2 while the modification value is 0.8 . In the original Chansons equation (1995), the equation for Ce was $0.9 \sin a$, whereas in the modified Chansons equation (1995), the equation of $\mathrm{Ce}$ is converted into $0.6 \mathrm{sin}$ a. Moreover, the modified equations of Straub and Anderson (1958) are preferred to predict the distribution of air concentration at the vertical direction in the developing zone at the self-air entrainment condition than the modified equation of Chanson (1995). Whereas, the proposed equation by Straub and Anderson (1958) especially in the underlying zone with air concentration was at $\mathrm{zt} / 2$ was equal to $0 \%$, then the parameter $\mathrm{CO}$ (air concentration at the inner edge of the turbulent free zone) was used, but if $z t / 2 \neq 0 \%$ (typically the air concentration reached the channel bed) then the parameter $\mathrm{Cl}$ (the air concentration at $\mathrm{zt} / 2$ ) was used. Finally, the modification equation of air bubbles distribution at self-air entrainment conditions in this study can be used to improve the prediction of results of distribution of air bubbles at the bed of the steep channel by using the Chanson (1995) and Straub and Anderson (1958) equations. The significant finding of this research is that the modified equation has a high accuracy of the actual air bubble distribution as compared to the original Chanson (1995) equation and Straub and Anderson equation (1958).

\section{Acknowledgement}

The authors would like to thank the Universitas Negeri semarang (UNNES) who has provided financial supportfor this research through the Excellent Research Scheme of Higher Education (PUPT) with the Decree of Decentralization Research Letter Number: 1.5.5/UN37 /PPK.3.1/2014, dated 5 May 2014.

\section{References}

[1] Bhajantri, M. R., Eldho, T. I., and Deolalikar, P. B. 2006. Hydrodynamic Modelling of Flow over a Spillway Using a Two-dimensional Finite Volume-based Numerical Model. Sadhana. 31 (6): 743-754.

[2] Falvey, H., T. 1980. Air Water Flow Hydraulic Structure.United States Department of Interior, Water and Power Resources Service.

[3] Bentalha, C. 2016. Numerical Study of Turbulent Flow for Moderate Slope Stepped Spillways. Malaysian Journal of Civil Engineering. 30(1): 57-68.

[4] Kramer, K. and Hager, W. 2005. Air Transport in Chute Flow. International Journal of Multyphase Flow. 3(11): 1181-1197.

[5] Lay, K. K. 1968. A Study of Air Entrainment in Steep Open Channel. Paper No. 2641. Conference on Hydraulics and Mechanics, Sydney. 41-44.

[6] Viparelli, M. 1953. The Flow in Flume with 1:1 Slope. Proc., MIHC. 417.

[7] Straub, L. G., and Anderson, A. G. 1958. Experiment on Self Aerated Flow in Open Channels. Proc. ASCE. 84(7): 1890.

[8] Chanson, H. 1995. Air Bubble Diffusion in Supercritical Open Channel Flows. Proc. AFMC. 2(12): 707-710.

[9] Afshar, N., R., Raju, R., and Asawa, G., L. 1994. Air Concentration Distribution in Self-Aerated Flow. Journal of Hydraulic Research. 32(4): 623-631.

[10] Sutopo, Y., Budi, S. W., Bambang, Y., and Istiarto. 2014. Aerator Performance in Reducing the Phenomenon of Cavitation on Supercritical Flow at the Bed of a Steep Channel. Research Report PUPT UNNES. Universitas Negeri Semarang, Indonesia.

[11] Dermawan, V., Legono, Dj., and Krisnayanti, D. S. 2017. Prediction of Dissolved Oxygen on Stepped Spillway with Different Configuration. Jurnal Teknologi. 79(4): 73-79.

[12] Krisnayanti, D., S., Suharjono, and Dermawan, V. 2016. Flow and Energy Dissipation Over on Flat and Pooled Stepped Spillway. Jurnal Teknologi. 78(8): 79-86.

[13] Taylor, J. R. 1997. An Introduction to Error Analysis: The Study of Uncertainties in Physical Measurements. Mill Valley. Calif University Science Books.

[14] Hydar, L., Ali., T., A., M., Badronnisa, Y., and Azlan A. A. 2016. Testing the Accuracy of Sediment Transport Equations Using Field Data. Malaysian Journal of Civil Engineering. 28 Special Issue (1): 50-64.

[15] Ayob, K., and Mohd Z., M., Y. 2003. Flood Potential Estimation of Two Small Vegetated Watersheds. Jurnal Kejuruteraan Awam. 15(1): 1-15. 